\title{
ANTIPROLIFERATIVE ACTIVITY OF RECOMBINANT HUMAN INTERFERON ALPHA2B ON ESTROGEN POSITIVE HUMAN BREAST CANCER MCF-7 CELL LINE
}

\author{
Ratih Asmana Ningrum*, Popi Hadi Wisnuwardhani, Adi Santoso \\ Neng Herawati
}

Research Center for Biotechnology, Indonesian Institute of Sciences Jalan Raya Bogor km 46 Cibinong, West Java, Indonesia, 16911

Submitted: $28-10-2014$

Revised: 10-02-2015

Accepted: $20-03-2015$

${ }^{*}$ Corresponding author Ratih Asmana Ningrum

Email:

ratih.asmana.ningrum@lipi.go.id

\section{INTRODUCTION}

$\mathrm{hIFN} \alpha-2 \mathrm{~b}$ is a glycoprotein that consist of 166 amino acids with O-glycosylated threonine at position 106. It has two disulfide bonds that are formed by cysteines at position 1 and 98 as well as 29 and 138 . hIFN $\alpha-2 b$ has been used as therapeutic protein on several cancer treatments. These include melanoma, renal cell carcinoma, AIDS related Kaposi's sarcoma (KS), follicular lymphoma, hairy cell leukemia, and chronic myelogenous leukemia (CML). Its antiproliferative activity on cancer cells covers direct and indirect activities. Direct activities are growth inhibition by cell cycle arrest, apoptosis, or differentiation. Indirect activities are activation of immune cells such as $\mathrm{T}$ cells and natural killer cells, inhibition of vascularization (antiangiogenesis), and induction of cytokines (Wang et al., 2002; Bekisz, 2010; Jonash and Haluska, 2000).

The antiproliferative activity is initiated by activation of JAK STAT pathway which interference to MAPK pathway that control a variety of processes in the cell, such as proliferation, differentiation, survival, and apoptosis. hIFN $\alpha-2 b$ can inhibit extracellular signal-regulated kinase (ERK) mitogen ERK kinase (MEK) pathway as a group of MAPK (Sarkar, 2003; Bekisz, 2010; Ningrum, 2014). rhIFN $\alpha-2 b$ as antiproliverative protein is applied as monotherapy or combination therapy with other cancer drugs, such as vinblastine, 5-fluorouracil, tamoxifen, or interleukin-2 (Jonash and Halusca, 2000). The synergistic antitumor effects of a combination of interferon and tamoxifen on estrogen 
receptor-positive and receptor- negative human tumor cell lines have been reported by Lindner and Borden (1997). Sequential treatment of MCF-7 cells in vitro with tamoxifen followed by IFN- $\alpha$ resulted in growth inhibition, suggesting that tamoxifen modulated the anticellular response to IFN- $\alpha$.

We developed rhIFN $\alpha-2 b$ in methilotropic yeast Pichia pastoris. The wildtype and $\mathrm{Mut}^{+} \mathrm{X}-33$ strain was used as a host. Other reports used GS115 strain which has mutation in the histidinol dehydrogenase gene (his4) that prevents it to synthesize histidine. So, It allow the selection of expression vectors containing HIS4 upon transformation (Shi et al., 2007; Ghosalkar et al., 2008; Li et al., 2007). Our rhIFN $\alpha-2 b$ was produced as extracellular protein with $24.05 \mathrm{kDa}$ in size containing polyhistidine tag and c-myc epitope in its C terminus. The yield on optimized condition was $28 \mathrm{mg} / \mathrm{L}(\mathrm{OD} 600=2.45)$. The characterization has been performed based on molecular weight by using SDS PAGE and specific antibody recognition by Western blotting methods (Ningrum, 2013; Santoso, 2013; Herawati, 2014). This research was purposed to characterize the rhIFN $\alpha-2 b$ based on amino acid sequence by using mass spectrometry MALDI TOF TOF and to study its in vitro antiproliferative activity. We studied the activity of our rhIFN $\alpha-2 b$ in combination with tamoxifen on esterogen reseptor-positive MCF-7 cell line as a model.

\section{MATERIAL AND METHODS Clone, media and strain}

Clone number 12 (methylotrophic yeast Pichia pastoris strain X-33 harboring hifn $\alpha-2 \mathrm{~b}$ ORF) that has been selected by using $2000 \mu \mathrm{g} / \mathrm{mL}$ of zeocin from our previous study was used (Ningrum et al., 2013). BMGY (1\% yeast extract, $2 \%$ peptone, $100 \mathrm{~mm}$ potassium phosphate ph 6, 1.34\% YNB, 1\% glycerol) and BMMY (1\% yeast extract, $2 \%$ peptone, $1.34 \%$ $\mathrm{YNB}$ and $0.5 \%$ methanol) were used in protein overproduction.

\section{Overproduction, purification characterization of rhIFNa-2b}

and

Single colony was grown overnight in $50 \mathrm{~mL}$ BMGY medium at $30^{\circ} \mathrm{C}$ and $250 \mathrm{rpm}$ until $\mathrm{OD}_{600}=2-6$. The culture was centrifuged at $1500 \mathrm{x} \mathrm{g}$ for $5 \mathrm{~min}$. The pellet was resuspended in $100 \mathrm{ml}$ BMMY medium $\left(\mathrm{OD}_{600}=1.0\right.$, the media was containing $0.5 \%$ methanol as inducer). The methanol induction was repeated at $24 \mathrm{~h}$ of cultivation time. Harvesting was performed by centrifugation at $1500 \mathrm{x} \mathrm{g}$ for $5 \mathrm{~min}$ at room temperature to collect the supernatant. Phenylmethylsulfonyl fluoride $1 \mathrm{mM}$ was added and used as protease inhibitor. Ultrafiltration was carried out by using Minimate ${ }^{\text {TM }}$ TFF system (PALL) with molecular weight cut off was $10 \mathrm{kDa}$. $100 \mathrm{~mL}$ of supernatant was concentrated into $10 \mathrm{~mL}$. The concentrated fraction then purified by AKTA purifier 10 system using His trap column (GE Healthcare). $10 \mathrm{mM}$ of sodium phosphate containing $20 \mathrm{mM}$ imidazol and $500 \mathrm{mM}$ sodium chloride was used as washing buffer. Elution buffer composition was $10 \mathrm{mM}$ of sodium phosphate, $500 \mathrm{mM}$ imidazol and $500 \mathrm{mM}$ sodium chloride. Purified protein was characterized by SDS PAGE. Its concentration was quantified based on bicinchoninic acid assay (BCA protein kit, Pierce) by using various concentrations (25 to $2000 \mu \mathrm{g} / \mathrm{mL}$ ) of bovine serum albumin as standard. The purple colored product was read at $562 \mathrm{~nm}$. The SDS PAGE band slices of protein were dried and characterized based on amino acid sequence of rhIFN $\alpha-2 b$ was performed by using MALDI TOF TOF (Proteomic Inc). The peptides were derived by trypsine cleavage.

\section{Antiproliferation assay \\ Cell cultivation and treatments}

MCF-7 cells (from mammalian cell culture laboratory, Indonesian Institutes of Sciences) were thawed and washed with $9 \mathrm{~mL}$ of DMEM medium containing penicillin (100units $/ \mathrm{mL}$ ) and streptomycin $(100 \mathrm{mg} / \mathrm{mL})$. Cells were grown in the same medium containing $10 \%$ fetal bovine serum (FBS) at $37^{\circ} \mathrm{C}$ and $5 \% \mathrm{CO}_{2}$. After $90 \%$ of confluency, the cells were washed with phosphate buffer saline (1.15 g Na2HPO4; 0.2g KH2PO4; $8 \mathrm{~g}$ $\mathrm{NaCl}$ and $0.2 \mathrm{~g} \mathrm{KCl}$ perliter, $\mathrm{pH} 7.2$ ) and detached with $500 \mu \mathrm{L}$ of trypsin-EDTA $(0.25 \%$ trypsin in $0.53 \mathrm{mM}$ EDTA) at $37^{\circ} \mathrm{C}$ for $5 \mathrm{~min}$. The cells were transferred into a 96 well $(3000$ cell/well) or 24 well plate (15.000/ well) for further study. The cells were grown overnight in DMEM media containing penicillin- 
streptomycin with 5\% FBS, washed with 100 $\mu \mathrm{L}$ of PBS and treated by $1 \mu \mathrm{M}$ tamoxifen (Merck) overnight. Further treatment was applied by various concentration of $h I F N \alpha-2 b$ for 5 days. We used $\operatorname{rhIFN} \alpha-2 b$ standard to validate the assay. The treatment conditions were based on a report by Lindner and Borden (1997) with some modifications.

\section{MTT Assay}

Treated cells in 96 well plates were washed twice with $100 \mu \mathrm{L}$ of PBS. $100 \mu \mathrm{L}$ of DMEM with 5\% FBS containing MT'T (with final concentration $0.5 \mathrm{mg} / \mathrm{mL}$ ) was added to each well. Cells were then incubated for $3 \mathrm{~h}$ and the medium was discarded. Formazan crystals formed at the bottom of the well were dissolved in $100 \mu \mathrm{L}$ of SDS $10 \%$. The cells were incubated for overnight. The reaction was stopped by $0.01 \mathrm{M} \mathrm{HCl}$ and dissolved formazan was measured at $570 \mathrm{~nm}$. The percentage of viable cell was compared to control (untreated cells). The experiments were done in triplicates in three dependent experiments (Septisetyani et al., 2014). The statistical analysis was performed by student $\mathrm{T}$ test.

\section{Viability Staining}

Treated cells in 24 well plates were washed twice with $1 \mathrm{~mL}$ of PBS and stained with $500 \mu \mathrm{L}$ of $2 \mu \mathrm{M}$ calcein $\mathrm{AM}$ and $4 \mu \mathrm{M}$ ethidium bromide. The cells were incubated at room temperature for $45 \mathrm{~min}$ and observed under fluorescence microscope (Life technologies) at $485 \mathrm{~nm}$ of excitation wavelenght. The experiments were done in triplicates in three dependent experiments.

\section{RESULTS AND DISCUSSIONS Overproduction, Purification Characterization of rhIFNa-2b}

and

Overproduction was performed by using optimal condition from previous research (Herawati, 2014). Molecular weight characterization of concentrated supernatant by SDS PAGE showed a protein band at $24 \mathrm{kDa}$ as its theoretical size. The different size of our protein compared to the native form was due to the presence of polyhistidine tag and c-myc epitope sequences at $\mathrm{C}$-terminus. Purification of the rhIFN $\alpha$ - $2 \mathrm{~b}$ protein was performed based on interaction between Ni-NTA resin and polyhistidine tag at C-terminus of the protein. The impurities were removed by using $20 \mathrm{mM}$ of histide analog imidazole and $500 \mathrm{mM}$ of sodium chloride as previously reported by Bornhorst and Falke (2000). The chromatogram showed absorbance peak at elution fractions (C3 to C5) that corresponding to purified rhIFN $\alpha 2 \mathrm{~b}$ (Figure 1). The unpurified and purified $\mathrm{rhIFN} \alpha-2 \mathrm{~b}$ was shown in figure 2 .

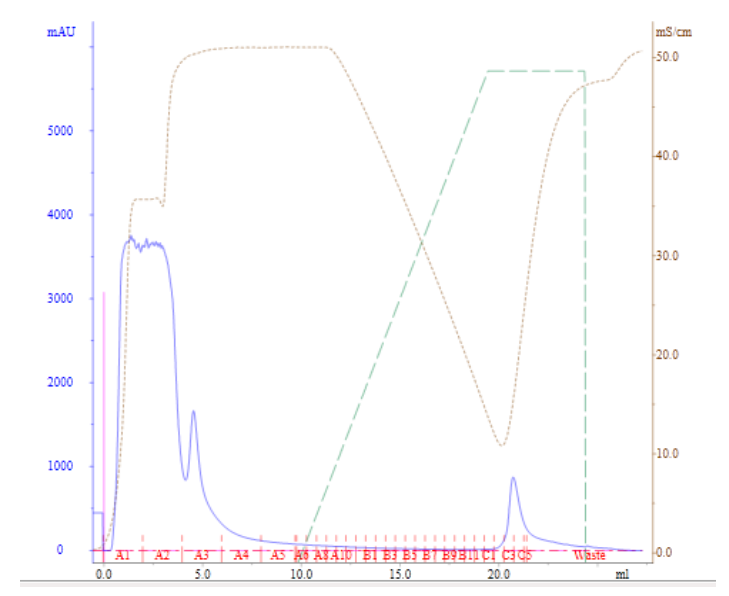

Figure 1. Purification of $\operatorname{rhIFN} \alpha 2 \mathrm{~b}$. A1-A10= flow through fractions; $\mathrm{B} 1-\mathrm{B} 11=$ washing fractions and $\mathrm{C} 1$ to $\mathrm{C} 5=$ elution fractions
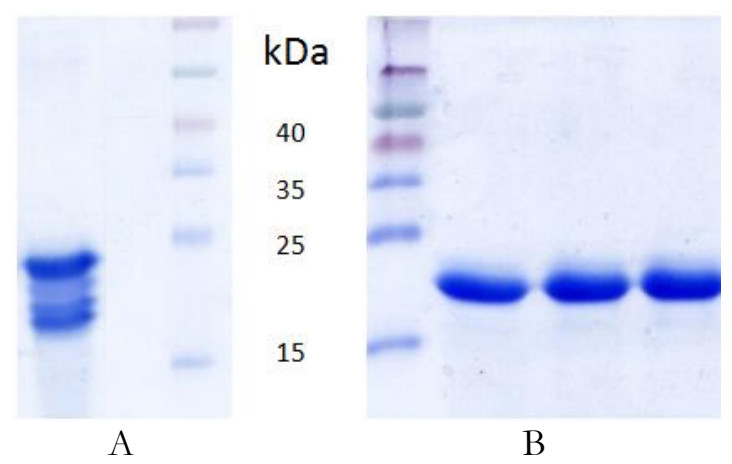

Figure 2. Characterization of $\operatorname{rhIFN} \alpha-2 b$ : A. Unpurified ; B. Purified

Protein identity characterization was performed by amino acid sequence determination. Trypsin was used as protease enzyme on MALDI TOF TOF mass spectrometry analysis. Peptide summary report identified the protein as $\mathrm{hIFN} \alpha-2 \mathrm{~b}$. There were five peptide fragments which matched with hIFN $\alpha-2 b$ sequence: K.EDSILAVR.K; 


\section{CDLPQTHSLGSRRTLMLLAQMRKISLFSCLKDRHDFGFPQEEFGNQFQKAETIPVL HEMIQQIFNLFSTKDSSAAWDETLLDKFYTELYQQLNDLEACVIQGVGVTETPLMK EDSILAVRKYFQRITLYLKEKKYSPCAWEVVRAEIMRSFSLSTNLQESLRSKE}

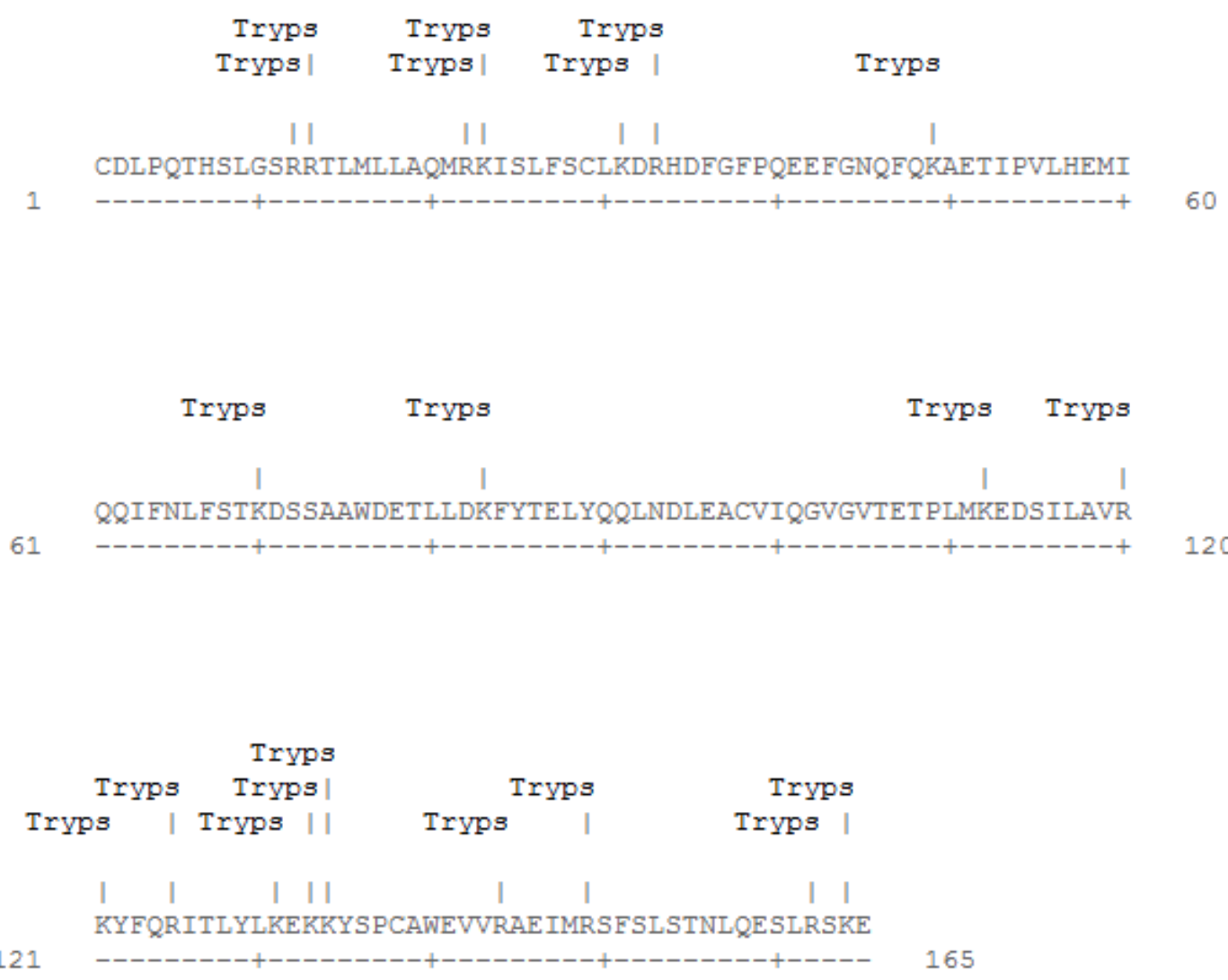

Figure 3. Amino acid sequence determination by MALDI TOF TOF and proteolytic cleavage site of trypsin in $\mathrm{hIFN} \alpha$-2b by using peptide cutter (Expasy). The identified residues were shown in red.

\begin{abstract}
R.ITLYLKEK.K; R.SFSLSTNLQESLR.S; R.HDFGFPQEEFGNQFQK.A and K.DRHDFGFPQEEFGNQFQK.A. These fragments covered 55 amino acid residues or $33 \%$ of the $\mathrm{hIFN} \alpha-2 \mathrm{~b}$ sequence. Based on trypsin cleavage sites analysis by using Expasy peptide cutter software, there were 20 sites of trypsin cleavage in the $\mathrm{hIFN} \alpha-2 \mathrm{~b}$ sequence (Figure 3). Lower amino acid coverage found in this research may be caused by impurities in the sample. This research used one dimensional electrophoresis on sample preparation. According to Gonnet et al (2003), this kind of preparation may lead to more than one protein per gel bands so the suppression effect can occur and causing poor coverage of protein sequence.
\end{abstract}

\section{Antiproliferation assay}

There were many cancer drugs that have been previously applied in combination with hIFN $\alpha 2-b$ in cancer treatments, such as leucovorin, vinblastine, 5-fluorouracil, tamoxifen, interleukin-2, retinoic acid or folinic acid (Taylor et al., 1992; Jonash and Haluska, 2000; Lee et al., 1992; Lindner et al., 1997; Bernhard et al., 1992). Tamoxifen is cellpermeable and reversible inhibitor of protein kinase C. It induces apoptosis in human malignant glioma cell lines and inhibits prostate cancer cell growth by induction of p21 protein. Tamoxifen is a potent synthetic anti-estrogenic agent. It is cytostatic for estrogen-dependent cell line. Estradiol binds to estrogen receptor (ER) in ER positive cell and induces 
Antiproliferative Activity

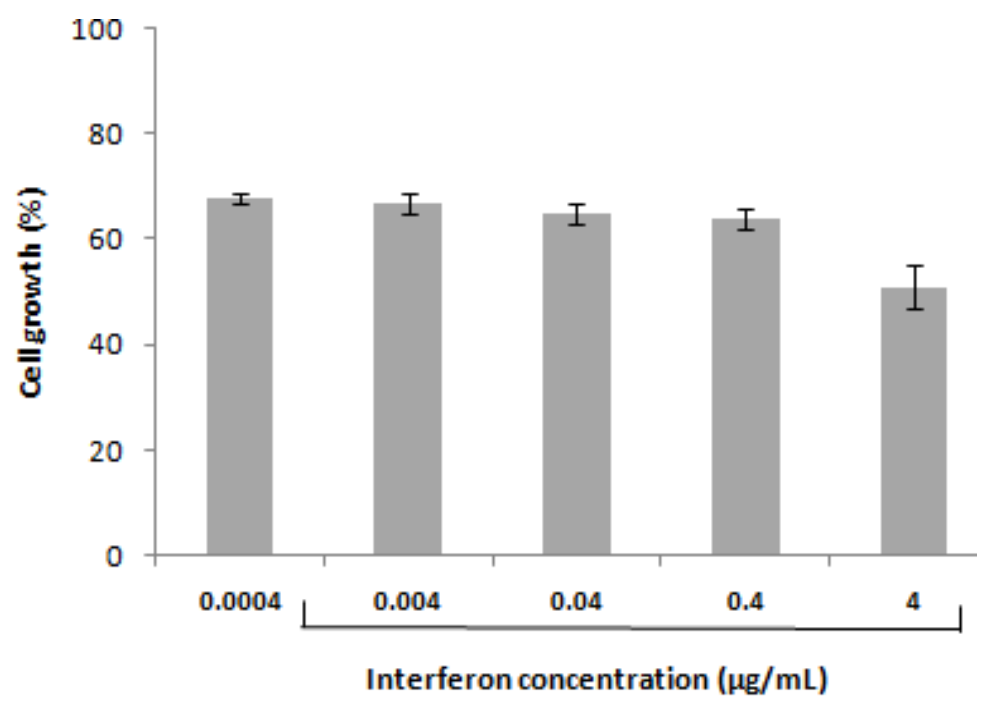

Figure 4. MCF-7 cell line growth inhibition by rhIFN $\alpha-2 b \quad(\mathrm{P}<0.0001)$.

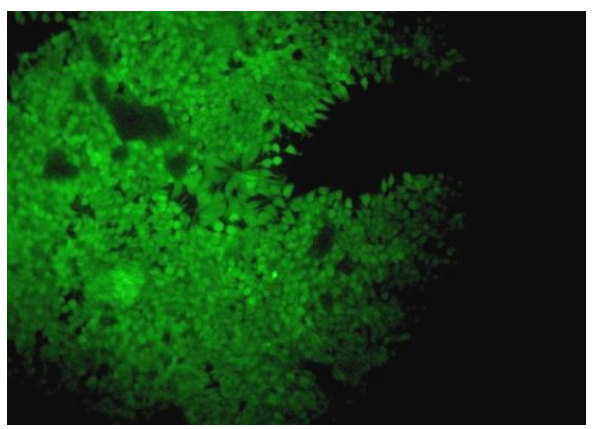

A

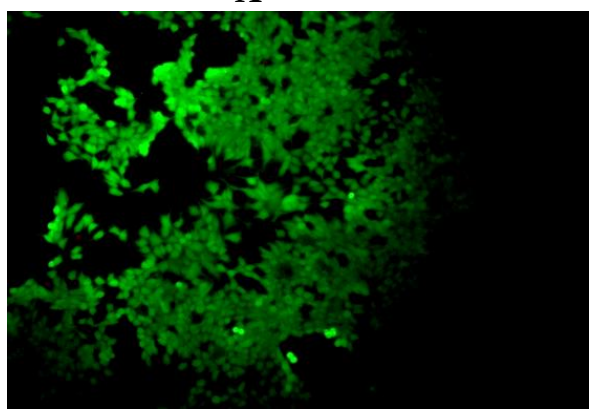

C

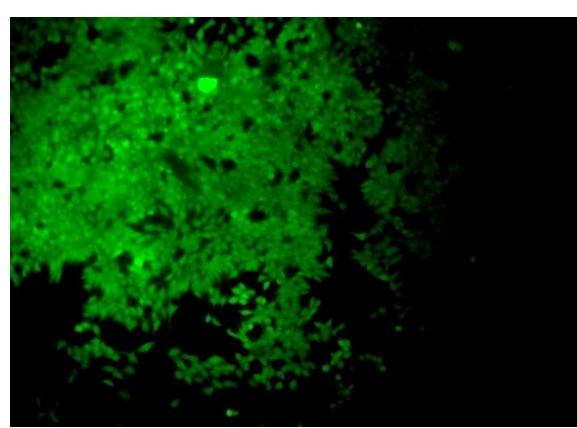

B

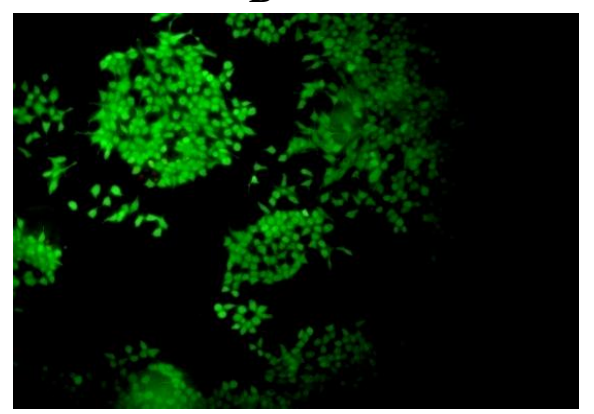

D

Figure 5. Calcein AM and Ethidium bromide-based staining of MCF-7. A=untreated, B, C, D= treated by tmx $1 \mu \mathrm{M}$, $\operatorname{rhIFN} \alpha-2 \mathrm{~b}$ standard and $\operatorname{rhIFN} \alpha-2 \mathrm{~b}$ in sequence.

transcription to promote growth. Tamoxifen competes with estrogen for binding to the receptor, so growth inhibition occurs (Lippman and Bolan, 1975). MCF-7 is human breast adenocarcinoma and ER positive cell line. We used MCF-7 as a model based on several studies which report that IFN- $\alpha$ has inhibitory effect on its proliferation and adhesion (Maemura et al., 1999; Robinson et al., 1990; Porta, 2004; Tiwari et al., 1991 ; Lindner et al., 1997).

Antiproliferative activity was performed as reported by Lindner and Borden (1997) with some modifications. Sequential treatment of 
MCF-7 cell with tmx and rhIFN $\alpha-2 b$ was performed. According to previous study, tmx can modulate the anticellular response to rhIFN $\alpha 2$-rather than the opposite. Since the IC50 is $100 \mu \mathrm{M}$ and to make sure that it has less cytostatic effect, as much as $1 \mu \mathrm{M}$ of tmx was applied (Lindner and Borden, 1997). After 5 days of treatment with $\operatorname{rhIFN} \alpha-2 b$, the viable cells were undirectly counted by using MT'T assay. Figure 4 showed that growth inhibition of MCF-7 cell line was dose dependent and the highest inhibition was achieved at $4 \mu \mathrm{g} / \mathrm{mL}$. This result was in line with previous publication which reported activity of rhIFN $\alpha 2$-b on HepG2. This study used $\operatorname{rhIFN} \alpha-2 b$ that produced in E. coli BL21 (DE3) as mentioned in our previous work (Ningrum et al., 2012). Most publications on biological activity of rhIFN $\alpha 2$-b determination were used viral cytophatic inhibition as the observed parameter. (Srivasta et al., 2005; Valente et al., 2005; Neves et al., 2004; Essafi et al., 2007).

Antiproliferative activity of our $\mathrm{rhIFN} \alpha$ $2 \mathrm{~b}$ was also studied by using calcein AMEthidium bromide III double staining method. The assay was founded on the measurement of two recognized parameter of living cells, intracellular esterase activity and plasma membrane integrity. Calcein AM is nonfluorescent cell-permeant that can be enzimatically converted into intensely fluorescent calcein (Papadopoulos et al., 1994). The polyanionic dye calcein is retained within the living cells producing green fluorescence. Ethidium bromide III is excluded by intact plasma membrane of live cells and is $40 \%$ brighter than Ethidium bromide I (Papadopoulos et al., 1994). In this study, the highest concentration of $\operatorname{rhIFN} \alpha-2 \mathrm{~b}$ was applied to treat MCF-7 cells and the result was compared with the effect of $1 \mu \mathrm{M}$ tmx in treated and untreated cells. As a positive control, rhIFN $\alpha-2 b$ protein obtained from Biovision was used. The result showed that untreated cells had higher growth than the treated ones. As mentioned earlier, the treatment of tmx at $1 \mu \mathrm{M}$ of concentration did not give any significant growth inhibition. Our rhIFN $\alpha-2 b$ had comparable ability to inhibit MCF-7 growth (Figure 5). This result strongly indicated that our rhIFN $\alpha-2 b$ was biologically active. This preliminary study must be confirmed with other methods, such as cell cycle analysis by flowcytometry or gene expression by real time PCR.

Mechanism of action of $\mathrm{hIFN} \alpha 2 \mathrm{~b}$ in influencing the growth of a variety of cells occurs through the JAK-STAT signal transduction. JAK-STAT pathway associated with the MAPK pathway as a major pathway in cell proliferation. Proteins that play a role in MAPK is the protein $G$ and three protein kinases, namely MAPK kinase kinase (MAPKKK), MAPK kinase (MAPKK), and MAPK. MAPKKK can phosphorylate and activate the MAPK protein kinase (MAPKK), and MAPKK can activate MAPK. hIFN $\alpha 2 b$ can inhibit extracellular signal-regulated kinase pathways (ERK) mitogen ERK kinase (MEK) that belong to the MAPK pathway (Chiariello $e t$ al., 2000; Kolch, 2000; Romerio and Zella, 2002). Study of ERK inhibition of MEK by hIFN $\alpha 2 b$ been widely reported. Several publications reported that the inhibition of proliferation occurred because $h I F N \alpha 2 b$ induced PP2A enzyme that inactivated the ERK and MEK proteins. hIFN $\alpha 2 b$ also regulates the docking protein that inhibits the interaction of MEK or ERK by MEK interactions with other kinases. Inhibition of protein will decrease the activity of cyclindependent kinase (CDK-2 and CDK-4) and lower protein expression of cyclin $\mathrm{D}$ and $\mathrm{E}$ which involve in cell proliferation. The Inhibition also increases p21 Waf1 and p27 kip1 as an inhibitor of cell division and decreases protein phosphorylation RB / p105 (Romerio et al., 2000; Romerio and Zella, 2002; Steelman, 2004). The antiproliferative activity of rhIFN $\alpha 2 b$ also occurs by apoptosis mechanism. There are two major pathways of apoptosis through the receptor family of tumor necrosis factor alpha (TNF- $\alpha$ ) and cytochrome c release by mitochondria. Both of these pathways activating caspase signaling cascade that results in DNA fragmentation and cell death (Bekisz et al., 2010; Bazhanova, 2003; Ningrum, 2014).

\section{CONCLUSIONS}

The rhIFN $\alpha-2 b$ that used in combination with antiestrogenic tamoxifen had antiproliferative activity. It's activity on 
estrogen positive human breast cancer MCF-7 cell line was dose dependently.

\section{ACKNOWLEDGEMENT}

The authors would like to thanks to Endah Puji Septisetyani from research center for biotechnology, Indonesian Institute of Sciences, for her kindly assistance in this research.

\section{REFERENCES}

Bekisz J., Baron S., Balinsky C., Morrow A., Zoon KC. 2010. Antiproliferative properties of type I and type II interferon. Pharmaceuticals, 3, 994-1015.

Bernhard H., Jäger-Arand E., Bernhard G., Heike M., Klein O., Riemann JF., Meyer zum Büschenfelde KH., Dippold W., Knuth A. 1995. Treatment of advanced pancreatic cancer with 5-fluorouracil, folinic acid and interferon alpha-2A: results of a phase II trial, Brit J. Cancer. 71(1): 102-105.

Bornhorst JA., Falke JJ. 2000. Purification of Proteins Using Polyhistidine Affinity Tags. Methods in Enzymol. 326: 245-254.

Chiariello M., Gomez E., Eliana, Gutkind JS., (2000. Regulation of cyclin-dependent kinase (Cdk) 2 Thr-160 phosphorylation and activity by mitogen-activated protein kinase in late G1 phase, Biochemistry Journal, 349, 869-876.

Essafi IR., Sadok A., Khalaf N., Fathallah DM. 2007. A strategy for high-level expression of soluble and functional human interferon a as a GST-fusion protein in E.coli, Protein Eng, Des and Sel vol. 20 no. 5 pp. 201-209, 2007.

Ghosalkar A., Sahai V., Srivasta A., 2008. Secretory expression of interferonalpha2b in recombinant Pichia pastoris using three different secretion signals, Protein Expr. Purif.60: 103-109.

Gonnet F., Lemaitre G., Waksman G. Tortajada. 2003. MALDI/MS peptide mass fingerprinting for proteome analysis: identification of hydrophobic proteins attached to eucaryote keratinocyte cytoplasmic membrane using different matrices in concert, Proteome Science. 1:2, 1-7. Clinical Applications, and Toxicities, The Oncologist. 6: 34-55.
Herawati N., Santoso A., Ningrum RA. 2014. The Effect of non-nutritional factors of culture condition on Human Interferon alpha-2b Production in Methilotropic Yeast Pichia pastoris, J.Pharm. Bioanalitical Science. 3 (1): 1-5.

Kolch W. 2000. Review article: Meaningful relationship the regulation of the Ras/Raf/MEK/ERK pathway by protein interaction, Biochem. J., 351, 289-305.

Lee KH., Lee JS., Suh C., Lee YS., Min YI., et al., 1992. Combination of 5fluorouracil and recombinant interferon alpha-2B in advanced gastric cancer. A phase I study, Am. J. Clin. Oncology. 15(2) : 141-145.

Li P., Anumanthan A., Gao XG., Ilangovan K., Suzara V., Diizgiines, Renugopalakrishnan R., 2007, Appl. Biochem Biottechnol. 142: 105-124.

Lindner DJ., Borden EC. Alvakolanu DV. 1997. Synergistic antitumor effects of a combinantion of interferons and retinoic acid on human tumor cells in vitro and in vivo, Cin. Can. Res. 3: 931-937.

Lindner DJ., Borden EC. 1997. Synergistic Antitumor Effects of a Combination of Interferon and Tamoxifen on Estrogen Receptor-Positive and Receptor-Negative Human Tumor Cell Lines In Vivo and In Vitro. J. Interferon Cytokine Res. 17: 681-693.

Lippmann ME., Bolan G. 1975. Oestrogenresponsive human breast cancer in longterm tissue culture. Nature, 256,593-595.

Maemura M., Iino Y., Horiguchi J., Takei, H., et al., 1999. Effects of interferon-alpha on cellular proliferation and adhesion of breast carcinoma cells, Oncology reports. 6(3): 557-561

Neves FO., Ho PL., Raw I., Pereira CA., Moreira C., Nascimento ALTO. 2004. Overexpression of A Synthetic Gene Encoding Human Alpha Interferon in Escherichia coli, Protein Expression and Purif. 35: 353-359.

Ningrum RA. 2014. Interferon alpha2b: a therapeutic protein for cancer treatment. scientifica,1-8.

Ningrum RA., Santoso A., Herawati N. 2013. Secretory Expression of Recombinant Human Interferon-alpha2b in 
methilotropic yeast Pichia pastoris, Int. J.Res. in Pharm. Scie.. 4(2): 207-210.

Ningrum RA., Rahmatika DE., Retnoningrum DS., Wangsaatmadja AH., Sumirtapura YC., Rachmawati H. 2012. Development of Novel Interferon Alpha2b Muteins and Study the Pharmacokinetic and Biodistribution Profiles in Animal Model, J. Biomed. Sci. Eng. 5: 104-112.

Papadopoulos NG., Dedoussis GV., Spanakos G., Gritzapis AD., Baxevanis CN., Papamichail M. 1994. An improved fluorescence assay for the determintion of lymphocyte-mediated cytotoxicity using flocitomety, J.Immunology methods.

Robinson SP., Goldstein D., Witt PL., Borden EC., Jordan VC. 1990. Inhibition of hormone-dependent and independent breast cancer cell growth in vivo and in vitro with the antiestrogen toremifene and recombinant human interferonalpha 2, Breast Cancer Research Treament, 15(2):95-101.

Romerio F., Zella D., 2002. MEK and ERK inhibitors enhance the antiproliferative effect of interferon- $\alpha 2 b, F A S E B$ Journal, USA.

Romerio F., Riva A., Zella D. 2000. Interferon alpha2b reduces phosphorylation and activity of MEK and ERK throgh a Ras/Raf-independent mechanism, Brit. J.Cancer, 83, 532-538.

Porta C., Slimane RH., Nejmeddine M., Pampin M., Tovey MG., Lucile Espert., Alvarez S., Chelbi-Alix MK. 2005. Interferons $\alpha$ and $\beta$ induce p53dependent and p53-independent apoptosis, respectively. 24: 605-615

Santoso A., Ningrum RA., Herawati N. 2013. Purification and Characterization of Recombinant Human Interferonalpha2b in methilotropic yeast Pichia pastoris, Int. J.Pharm.Sci. Health Care. 3(3): 13-19. ISSN: 2249-5378.

Sarkar MC., Lindner DJ., Liu YF., Williams BR., Sen GC., Silverman RH., Borden EC. 2003. Apoptosis and interferons: role of interferon-stimulated genes as mediators of apoptosis, Apoptosis. 8: 237249.
Septisetyani EP., Ningrum RA., Romadhani Y., Wisnuwardhani PH., Santoso A. 2014. Optimization of sodium dodecyl sulphate as a formazan solvent and comparison of MTT assay with WST-1 assy in MCF-7 cells, Indonesian J. Pharm. 25(4): 245-254.

Shi L., Wang D., Chan W., Cheng L. 2007. Efficient expression and purification of human interferon alpha2b in the methilotropic yeast, Pichia pastoris, Protein Expr. Purif. 54: 220-226.

Srivastava, P., Bhattacharaya, P., Pandey, G. And Mukherjee, K.J. 2005. Overexpression and purification of recombinant human interferon alpha2b in Escherichia coli, Protein Expression Purif. 41: 313-322.

Steelman LS., Pohnert SC., Shelton JG., Franklin RA., Bertrand FE. McCubrey, JA., 2004. JAK/STAT, Raf/MEK/ERK, P13/Akt and BCR-ABL in cell cycle progression and leukemogenesis, Leukemia, 18, 189-218.

Taylor CW., Modiano MR., Woodson ME., Marcus SG., Alberts DS. Hersh, EM. 1992. A phase I trial of fluorouracil, leucovorin, and recombinant interferon alpha-2b in patients with advanced malignancy, Seminanr in Oncology. 19 (2 Suppl 3):185-190.

Tiwari RK., Wong GY., Liu J., Miller D., Osborne MP. 1991. Augmentation of cytotoxicity using combinations of interferons (types I and II), tumor necrosis factor-alpha, and tamoxifen in MCF-7 cells, Cancer Letter. 61(1):45-52.

Valente CA., Monteiro GA., Cabral JMS., Fevereiro M., Prazeres DMF. 2006. Optimization of the primary recovery of human interferon $\alpha 2 \mathrm{~b}$ from Escherichia coli inclusion bodies, Protein Expression Purif. 45: 226-234.

Wang YS.,Youngster S., Grace M., Bausch J., Borden R., Wyss DF. 2002. Structural and biological characterization of pegylated recombinant interferon alpha$2 \mathrm{~b}$ and its therapeutic implications, $A d v$. Drug Delivery Rev. 54: 547-570. 